\title{
Eğitsel Mobil Matematik Oyunu ile Sınıf İçi Oyunlaştırma: Bir Durum Çalışması Örneği ${ }^{1}$
}

\section{Gamification in the Classroom with the Educational Mobile Mathematics Game: A Case Study Example}

\begin{tabular}{|c|c|}
\hline \multicolumn{2}{|r|}{ Nuri KARA $^{2}$} \\
\hline $\begin{array}{l}\text { Anahtar Kelimeler } \\
\text { Oyunlaştırma, } \\
\text { mobil oyun, } \\
\text { eğitim, } \\
\text { matematik, } \\
\text { durum çalışması }\end{array}$ & 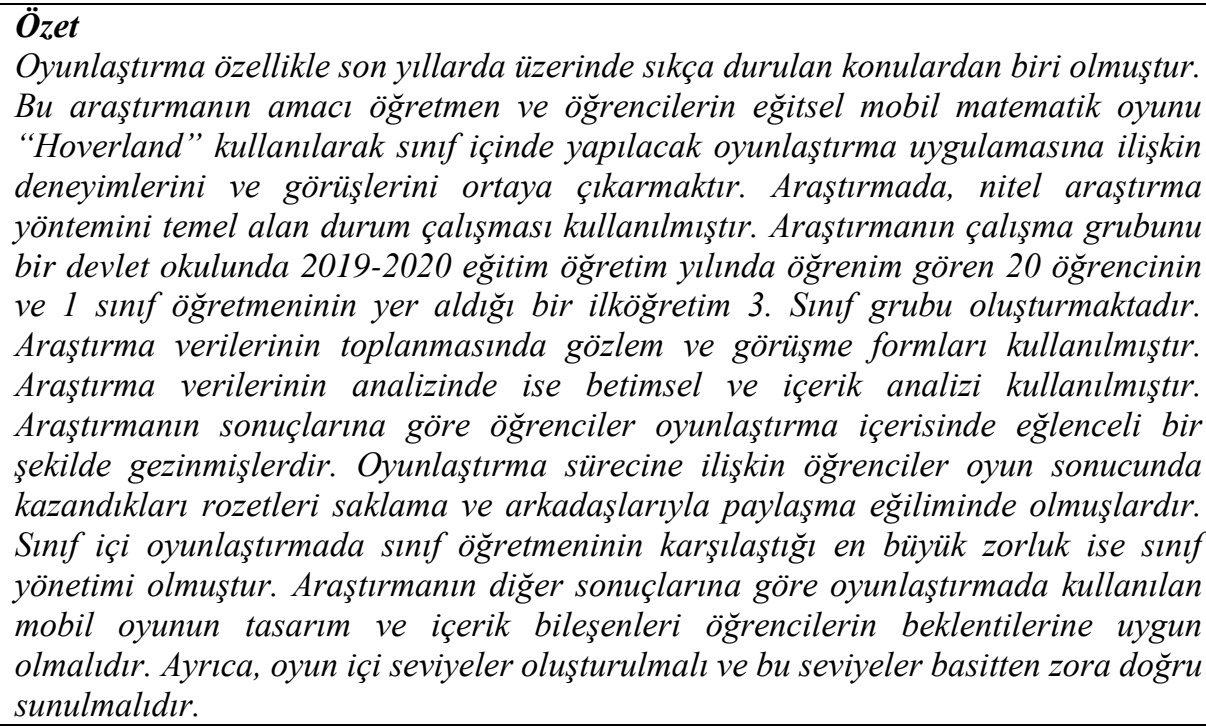 \\
\hline $\begin{array}{l}\text { Key Word } \\
\text { Gamification, } \\
\text { mobil game, } \\
\text { education, } \\
\text { mathematics, } \\
\text { case study }\end{array}$ & $\begin{array}{l}\text { Abstract } \\
\text { In recent years, gamification has been one of the hot topics in education. The main } \\
\text { goal of this study was to reveal experiences and views of primary school teacher and } \\
\text { students by doing gamification in class with the use of mobile "Hoverland" game Case } \\
\text { study which bases on the qualitative research method was used. The participants of } \\
\text { the study were } 1 \text { teacher and } 20 \text { students from a 3rd grade class in a state primary } \\
\text { school. Observation and interview forms were used to collect data. Descriptive and } \\
\text { content analysis were applied for analyzing data. Based on the results of the study, } \\
\text { students were attracted by the gamification process. In addition, students preferred to } \\
\text { save and share badges that they won by playing the game. Moreover, the teacher faced } \\
\text { difficulties in class management during the gamification. One of the results also } \\
\text { indicated that the mobile game used in gamification needs to be designed and } \\
\text { developed in accordance with the students'preferences. Besides, there is a necessity } \\
\text { of using levels in mobile game and ordering levels from easy to hard. }\end{array}$ \\
\hline
\end{tabular}

Atıf için:
For Citation

Kara, N. (2021). Eğitsel mobil matematik oyunu ile sınıf içi oyunlaştırma: bir durum çalışması örneği. Muğla Sitkı Koçman Üniversitesi Eğitim Fakültesi [MSKU Journal of Education], 8(1), 85-101. DOI: $10.21666 /$ muefd.764044

Received: 04.07.2020 Accepted: 27.11.2020 Published: 01.05.2021

Oyunlaştırma temel olarak oyun elementlerinin oyun dışı alanlarda kullanılmasıdır (Deterding, Dixon, Khaled ve Nacke 2011). Oyun elementleri genel olarak; oyun ara yüz bileşenleri, oyun mekanikleri,

\footnotetext{
${ }^{1}$ İlgili çalışmayl gerçekleştirmek için İstanbul Bilgi Üniversitesi İnsan Araştırmaları Etik Kurul tarafindan 12 Şubat 2019 tarihinde 2019-40660-15 sayll etik kurul izin belgesi alınmıştır. Bu araştırma BAP projesi kapsamında desteklenmiştir.

2 İstanbul Bilgi Üniversitesi, Illetişim Fakültesi, nuri.kara@bilgi.edu.tr, ORCID: 0000-0002-0115-383X
} 
oyun tasarım ilkeleri, oyun modelleri ve oyun tasarımı yöntemleri olmak üzere 5 ana bölümde değerlendirilmektedir. Bu bölümler ve açıklamaları alttaki Tablo 1'de sunulmaktadır:

Tablo 1

Oyun Elementleri ve Açıklamaları (Deterding ve diğ., 2011)

Oyun elementi Açılama Örnek

\begin{tabular}{|c|c|c|}
\hline $\begin{array}{l}\text { Oyun ara yüz } \\
\text { bileşenleri }\end{array}$ & $\begin{array}{l}\text { Oyunun oyuncu ile etkileşimini sağlayan } \\
\text { tüm görsel ve işitsel tasarım öğeleri }\end{array}$ & $\begin{array}{l}\text { Oyun içi rozetler, lider tahtası ve } \\
\text { farklı level seçenekleri }\end{array}$ \\
\hline Oyun mekanikleri & Oyunun oynanışına etki eden tüm olaylar & $\begin{array}{l}\text { Zaman kısıtlaması, sınırlı kaynakla } \\
\text { oyun içi dönüşler ve aksiyonlar }\end{array}$ \\
\hline $\begin{array}{l}\text { Oyun tasartm } \\
\text { ilkeleri }\end{array}$ & $\begin{array}{l}\text { Oyunun tasarımına ilişkin tüm oyun içi } \\
\text { ilke ve yönergeler }\end{array}$ & $\begin{array}{l}\text { Farklı oyun oynama stillerine } \\
\text { uygunluk ve oyun içi amaçların ne } \\
\text { olması }\end{array}$ \\
\hline Oyun modelleri & $\begin{array}{l}\text { Oyun içi deneyime ilişkin tüm } \\
\text { kavramsal altyapı }\end{array}$ & $\begin{array}{l}\text { Zorluk seviyesi, oyun içi fantezi } \\
\text { evreni ve oyun içi merak }\end{array}$ \\
\hline $\begin{array}{l}\text { yun tasarımı } \\
\text { ontemleri }\end{array}$ & $\begin{array}{l}\text { Oyun tasarımına ilişkin yöntem ve } \\
\text { uygulamalar }\end{array}$ & $\begin{array}{l}\text { Oyuncu testleri ve oyuncu temelli } \\
\text { tasarım }\end{array}$ \\
\hline
\end{tabular}

Oyunlaştırma ile tüm bu oyun elementlerinin oyun içermeyen alanlara doğru bir şekilde entegre edilmesi hedeflenmekte ve bu oyunlaştırmanın oyuncularda davranış değişikliği yaratması beklenmektedir. Tüm bu oyun elementlerinin, sunulacak ortam ve içeriğe uygun bir şekilde yapılandırılarak tasarlanması ve o ortam içinde kullanıcı gruba uygun bir şekilde sunulması, oyunlaştırmayı özellikle önceki yıllarda çokça geliştirilen eğitsel oyunlardan ayırmaktadır. Dicheva, Dichev, Agre ve Angelova (2015)'nın da belirttiği üzere, oyunlaştırma yaklaşımı oyunsal düşünmeyi içermekte ve tüm oyun elementlerini öğrencileri sürece dâhil etme ve motivasyonlarını arttırma için kullanmaktadır. Bu noktadan hareketle, salt bir eğitsel oyun geliştirmek oyunlaştırma yapmak anlamına gelmemektedir. Oyunlaştırmayı düzgün bir şekilde yapabilmek için ilgili oyun içinde kullanılacak tüm oyun elementlerinin sürece ve konu alanına uygun şekilde yapılandırılması ve ilgili oyunlaştırmanın yapılacağı konu alanıyla o süreç arasında anlamlı bir bağlantının kurulması gerekmektedir.

González ve Area (2013) eğitsel materyallerin oyunlaştırılmasına ilişkin araştırmalarının sonucunda oyun içinde sunulan içeriklerden öğrencilerin bilgi edindiklerini ve oyuncuların oyun oynama eylemlerine bağlı olarak bilişsel becerilerinin geliştiğini belirtmektedir. Buna ek olarak, dijital oyunlaştırma materyallerinin informal bir deneyim sunarak formal öğretimi çeşitlendirdiğini vurgulamıştır. Bir diğer bulguları ise dijitalleştirilmiş eğitsel materyaller için kullanılabilecek oyun mekanikleri ve bileşenleri önerileridir. İlgili oyun mekanikleri/bileşenleri ve açıklamaları Tablo 2'de sunulmaktadir.

Literatürde oyunlaştırmaya ilişkin farklı araştırmalar da bulunmaktadır. Domínguez ve diğ. (2013) yaptıkları araştırma sonucunda oyunlaştırma deneyimi yaşamış öğrencilerin uygulamalı ödevlerde daha yüksek puanlar aldıklarını ortaya çıkarmıştır. Jagušt, Botički ve So (2018) hikâye anlatımı, puan veya rozet toplama gibi basit oyun strateji veya mekaniklerinin kullanılarak sınıf içerisinde oyunlaştırmanın faydalı olacağını vurgulamıştır. Gatti, Ulrich ve Seele (2019) yaptıkları araştırma sonucunda geliştirdikleri oyunun sürdürülebilirlik kavramının üniversitedeki yönetim bölümü öğrencilerine farklı noktalarıyla öğretimi konusunda önemli bir destek oluşturduğunu belirtmiştir. 
Tablo 2

Ĕgitsel Materyallerde Kullanılabilecek Oyun Mekanikleri/Bileşenleri Önerileri (González ve Area, 2013)

Oyun

Açıklaması

mekaniği/bileşeni

İnsanların biriktirme özelliğine vurgu yapar. Örneğin, kitap, fotoğraf ve film

Koleksiyon biriktirme gibi.

Puanlar Gerçek hayatta en fazla kullanılan mekanik olarak adlandırılabilir. Örneğin, spor karşılaşmalarının sonuçları, okulda alınan puanlar ve bu puanlara göre başarılı ya da başarısız olma durumları. Puanlar gerçekleştirdiğimiz eylem veya eylemlere verilen sayısal değerlerdir.

Kiyaslamalar ve siniflandirmalar (lider tahtalarl) Sosyal bileşen olarak tanımlanır. Diğer kullanıcılarla kıyaslamayı ya da kategorilere ayrılmayı içerebilir. Lider tahtaları, kullanıcıların ün kazanma ya da kendini gösterme noktasında önemli bir örnektir. Ayrıca, kullanıcıların birbiriyle rekabet etmelerine olanak sağlar.

Oyun içi düzeyler veya Kullanıcı deneyimine veya uzmanlaşmasına bağlı olarak farklı düzeyler bölümler

Statü

Statü, oyuncunun elde ettiği puanlara göre sıralamadaki yerini gösterir. Kullanıcılar çoğunlukla en yüksek skoru elde etme motivasyonuna sahiptir. İnsanlar eylemlerinin sonucunda bir geribildirim almak isterler. Kişilere Geribildirim olumlu ve açıklayıcı geribildirimler vermek önemlidir. Örneğin, kullanıcıları motive etmek için verilebilecek puanlar, rozetler ve sanal madalyalar.

Kazanımlar Kazanımlar; tamamlanan ve başarılan eylemlerin karşılığında elde edilenlerin fiziksel veya sanal karşılığıdır. Örneğin, kilitli gözüken oyun için bir bölümün ilgili kazanıma ulaşıldığında oynanabilir duruma gelmesi.

Oyuncular kendileri için anlamlı gördükleri bir göreve daha fazla motive Anlamlandirma olurlar. Örneğin, öğrencilerin içinde yaşadığımız gezegeni kurtarmak için oyun içinde mücadele ederken çevre bilincini geliştirmeleri.

Oyunlaştırma konusunun popüler ve sürekli yükselen bir konu olması ve gelişen oyun teknolojileriyle birlikte daha da ilerlemesi bu konuda çalışan araştırmacı sayısını arttıracaktır. Fakat halihazırda oyunlaştırma konusunda yeterli sayıda araştırma bulunmamakta ve özellikle yöntemsel olarak da çeşidi arttırılmış araştırmaların eksikliği ön plana çıkmaktadır (Hamari, Koivisto ve Sarsa, 2014; Hanus ve Fox, 2015). Ayrıca, çeşitli oyunlaştırma elementleri de yeterli olarak incelenmemiş ve araştırması yapılmamıştır (Hamari ve diğ., 2014; Hanus ve Fox, 2015). Burada oyunlaştırma elementleri ile kastedilen oyun içi mekanikler, tasarım öğeleri ve konu alanıyla bağlantısı olabilir. Bu noktada çalışmaların önemli bir bölümü sürece odaklanmadan çok, yapılan oyunlaştırmayı test eden ve yargıya varmaya çalışan araştırmalar olarak karşımıza çıkmaktadır Jagušt ve diğ. (2018) literatürde oyunlaştırma alanındaki eksikliği şu şekilde ifade etmektedir:

Oyunlaştırmanın eğitsel ortamlarda kullanımına ilişsin artan popülaritesine rağmen oyunlaştırmanın hangi şartlar altında yapıldı̆̆ ve başarılı veya başarısı olduğuna iliş̧kin yeterli deneysel çalışma bulunmamaktadır. Var olan literatür, yapılan oyunlaştırmaların çoğunluğunun bireylerin algısını ve tutumunu ölçmeyi amaçlayan anketlerle sinırlı olduğunu göstermektedir. Hâlbuki daha geniş kapsaml, oyun oynama ve aktiviteleri yapma süreçlerine odaklanan deneysel araştırmalara ihtiyaç vardır. (s. 446).

Buna benzer olarak, Dicheva ve diğ. (2015)'in aşağıdaki bulgusu diğer önemli bir tespit olarak değerlendirilebilir:

Eğitimde oyunlaştırmaya ilişkin yapılan yayınların çoğu bazı oyun mekanizmalarının eğitim ortamlarında olası kullanımlarına iliş̧kindir. Oyun bileşenlerinin eğitim ortamlarına uygulandığı deneysel çalışmalar yetersiz ve belirsizdir. Bununla birlikte, çoğu deneysel çalışma oyunlaştırmanın başarıll veya başarısız sayllması için yeterli değerlendirme metodunu içermemektedir. Oyunlaştırmaya ilişkin mekaniklerin ve oyun tasarım bileşenlerinin nasıl uygulanacağına ilişkin deneysel çalışmalara ihtiyaç vardır (s. 83). 
Oyunlaştırma alanında çalışan çoğu araştırmacı oyunlaştırmanın doğru tasarlanıp iyi kullanılırsa öğrenmeyi destekleyip iyileştireceğine inanmaktadır (Dicheva ve diğ., 2015). Bu nedenle, spesifik eğitim içeriği ve ortamına uygulanabilecek ve kullanılan oyun elementlerinin öğrencileri motive etmedeki etkisini de dikkate alan deneysel çalışmaların yapılması gerekmektedir (Dicheva ve diğ., 2015). Burada motivasyon önemli bir kavram olarak görülebilir; çünkü oyunlaştırmanın öğrencilerin motivasyonunu arttırdığına yönelik pek çok bulgu vardır. Hamari ve diğ. (2014)'e göre, öğrenme hedeflerine göre yapılan oyunlaştırma verdiği eğlence hissinin yanı sıra öğrencilerin motivasyonunu arttırmakta ve öğrenme aktivitelerine katılımda önemli bir artış sağlamaktadır. Hanus ve Fox (2015)'a göre, oyunlaştırma öğrencileri sınıf içi aktivitelere dâhil etmede popülaritesini her geçen gün arttırmaktadır. Motivasyon akademik başarıyı arttırmada en önemli faktörlerden birisidir (Abramovich, Schunn ve Higashi, 2013; Buckley ve Doyle, 2014; van Roy ve Zaman, 2018). Araştırmacılar ve uygulayıcılar öğrencilerin motivasyonunu arttırmak için pek çok teknik arayışındadırlar ve oyunlaştırma da kullanılabilecek bu tekniklerden birisidir (van Roy ve Zaman, 2018). Eğitsel bir araç olarak oyunlaştırma öğrenmeyi kolaylaştırma, motivasyonu ve katılımı arttırma, ders etkileşimini geliştirme ve öğrencilerin bilgisini genişletme amacıyla eğitsel bir araç olarak kullanılmaktadır (Jagušt ve diğ., 2018). Doğru bir şekilde uygulandığında oyunlaştırma içsel motivasyonu ve katılımı arttırabilir ve eğitim sistemi içindeki tüm seviyeden öğretmenler için çok güçlü bir eğitsel materyal olabilir (Buckley ve Doyle, 2014; Jagušt ve diğ., 2018; Villagrasa, Fonseca, Redondo ve Duran, 2014).

Türkiye'de son yıllarda oyunlaştırmaya ilişkin çalışmaların sayısı artış göstermektedir. Literatür tarandığında araştırma makalelerinin çoğunlukta olduğu görülmektedir. Türkmen ve Soybaş (2019) oyunlaştırılmış matematik dersi ünitesinin 5. sınıf öğrencilerinin matematik dersindeki başarılarına ve tutumlarına etkisini araştırmıştır. Araştırmacıların gerçekleştirdiği nicel ve nitel analizler sonucunda istatistiksel olarak anlamlı bir fark ortaya çıkmasa da oyunlaştırılmış öğrenme ortamlarına katılan öğrencilerin başarı puanları daha yüksek bulunmuştur. Karayılan, Çakmak ve Güzel (2018) oyunlaştırmanın bir fen bilimleri dersi ünitesinin değerlendirmesinde kullanımının öğrencilerin fen bilimleri dersindeki başarılarına etkisini incelemiştir. Araştırmacılar gerçekleştirdikleri deneysel çalışma sonucunda oyunlaştırmanın öğrenci başarısını olumlu yönde etkilediği sonucuna ulaşmışlardır. Meşe ve Dursun (2018) harmanlanmış öğrenme ortamlarında kullanılan oyunlaştırma öğelerinin duygu, ilgi ve katılım düzeyleri üzerine etkisini incelemiştir. Araştırmacıların uyguladıkları nicel ve nitel analiz sonuçlarına göre oyunlaştırma öğrenciler tarafından ilgi çekici bulunmuş ve katılım düzeylerinde artış yaratmıştır. Sarı ve Altun (2016) öğretim sürecine entegre edilen oyunlaştırma bileşenlerinin öğrencilerin derse olan ilgi, motivasyon ve katılım düzeyleri üzerine etkisini incelemiştir. Nitel yaklaşımı temel alan araştırma sonucuna göre oyunlaştırma bileşenlerinin uygulandığı derslerde öğrencilerin ilgi ve motivasyonları ile katılım düzeylerinde artış yaşanmıştır. Yukarıdaki çalışmaların ortak özelliklerine bakıldığında daha çok öğrenci ilgi, başarı, motivasyon ve katılımını araştıran çalışmalar olduğu gözükmektedir. Bununla birlikte araştırmalarda öğrenme ortamlarına entegre edilmiş oyunlaştırma bileşenleri ön planda tutulmuştur. $\mathrm{Bu}$ çalışmanın literatürdeki oyunlaştırma çalışmalarından farkı, eğitsel mobil oyun temelinde oyunlaştırma araştırma yapmasıdır. Bu çalışmada entegre edilmiş oyunlaştırma bileşenleri yerine oyunlaştırmayı temel alarak geliştirilmiş eğitsel mobil oyun uygulamasının sınıf içinde kullanımı araştırılmıştır. Ayrıca bu çalışmada sınıf içi oyunlaştırma süreci nitel yöntemlerle detaylı olarak öğrenci ve öğretmen deneyimleri temelinde ele alınmıştır.

Özetlemek gerekirse, oyunlaştırma son zamanlarda üzerinde çokça durulan ve eğitim ortamlarına uygulanması noktasında destek gören bir kavramdır. Özellikle öğrencilerin motivasyonunu arttırma, sınıf içi öğretime alternatif bir yaklaşım getirme ve öğretmenler için destekleyici olma noktasında önemli bir potansiyel olarak görülmektedir. Literatüre bakıldığında farklı çalışmalar olmasına karşın geliştirilen oyunların oyunlaştırma yaklaşımına uygun bir şekilde uygulanması noktasında detaylı araştırmaların eksikliği ön plana çıkmaktadır. Bu noktadan hareketle, bu çalışmanın amacı öğretmen ve öğrencilerin eğitsel mobil matematik oyunu kullanılarak sınıf içinde yapılacak oyunlaştırma uygulamasına ilişkin deneyimlerini ve görüşlerini ortaya çıkarmaktır. Çalışma kapsamında yanıtı aranacak araştırma soruları şunlardır:

- Eğitsel mobil matematik oyunu ile gerçekleştirilen sınıf içi oyunlaştırmaya ilişkin öğretmen ve öğrencilerin deneyimleri nasıldır?

- Eğitsel mobil matematik oyunu ile gerçekleştirilen sınıf içi oyunlaştırmaya ilişkin öğretmen ve öğrencilerin görüşleri nelerdir? 


\section{Yöntem}

Araştırmada, nitel araştırma yöntemini temel alan durum çalışması (case study) kullanılmıştır. Yıldırım ve Şimşek (2011)'e göre durum çalışması, bir olgu ya da olayın tüm yönleriyle analiz edilmesine imkân tanıyan araştırma yöntemidir. Ozan Leymun, Odabaşı ve Yurdakul (2017) da durum çalışmasının özellikle karmaş̧ı konuların derinlemesine incelenmesine olanak tanıdığını belirtmiştir. Bu araştırmada da eğitsel mobil matematik oyunu kullanılarak yapılan sınıf içi oyunlaştırma sürecinin detaylı olarak incelenmesi hedeflenmiştir. Bir ilköğretim üçüncü sınıfa devam eden öğrenciler ile sınıf öğretmeni çalışmanın durumu olarak belirlenmiştir. Bir devlet okulundaki bir ilköğretim üçüncü sınıfının durum olarak seçilmesinde ilgili okul yönetiminin izni ve onayı alınmıştır. Ayrıca, sınıf öğretmeninin daha önceden oyun ve oyunlaştırma çalışmalarına katılmış olması diğer önemli bir kıstas olmuştur. İlgili çalışmayı gerçekleştirmek için İstanbul Bilgi Üniversitesi İnsan Araştırmaları Etik Kurul tarafından 12 Şubat 2019 tarihinde 2019-40660-15 sayılı etik kurul izin belgesi alınmıştır.

\section{Katılımcılar}

Araştırmanın çalışma grubunu İstanbul ili Eyüpsultan ilçesinde bulunan bir devlet okulunda 2019-2020 eğitim öğretim yılında öğrenim gören 20 öğrencinin ve 1 sınıf öğretmeninin yer aldığ 1 bir ilköğretim 3. Sınıf oluşturmaktadır. Çalışmayı gerçekleştirmek için İlçe Milli Eğitim Müdürlüğünden yasal izin alınmıştır. Bilgilendirilmiş gönüllü onam formları çalışmada yer alacak öğrencilerin velileri tarafından imzalanmıştır. Etik kurul izni ve okul yönetiminin izni ve onayı doğrultusunda bu ilköğretim grubunun çalışma grubu olarak seçilmesinin nedeni, sınıf öğretmeninin benzer oyun uygulamalarını daha önceden deneyimlemiş olması ve sınıfın da oyunlaştırmada kullanılabilecek akıllı tahta, bilgisayar vb. teknik donanıma sahip olmasıdır. Çalışmaya katılan öğrencilerin \%55'i erkek ve \%45'i kız öğrencidir. Öğrencilerin yaş ortalaması 8.5'dur. Sınıf öğretmeni kadın olup, yaşı 40'dır ve 15 yıllık öğretmenlik deneyimi bulunmaktadır.

\section{Veri Toplama Süreci}

İlköğretim öğrencilerinin sınıf içi oyunlaştırma deneyimlerini ortaya çıkarmayı amaçlayan bu çalışma kapsamında veri toplama süreci 2020 yılı Şubat ayı içerisinde gerçekleştirilmiştir. İki farklı derste sınıf öğretmeni "Hoverland" oyununu kullanarak dersini oyunlaştırmış ve öğrencilerin aktif katılımını sağlamıştır. Öğretmen her bir derste oyunu akıllı tahtaya yansıtarak sınıf içerisinde her öğrencinin en az 1 kere akıllı tahtaya gelip oyunu oynamasını sağlamıştır. Her öğrencinin oyun sonunda kazandığı yıldızları öğretmen not etmiş ve yıldız sayısına bağlı olarak matematik dehası, dört işlem uzmanı, geometri kraliçesi gibi statüler belirlemiştir. Bireyselin yanı sıra sınıf içerisinde gruplar oluşturarak, grup içerisinde üretici, yol gösterici, uygulayıcı ve aktarıcı rollerini her bir öğrenciye vererek o öğrenci grubunun ilgili oyunu oynayıp sınıf içerisindeki diğer arkadaşlarına sunmasını istemiştir. Bu şekilde oyun içerisinde sunulan becerilerin pekiştirilmesini ve daha kolay anlaş1labilmesini hedeflemiştir. Oyunlaştırma süreci 2 farklı derste her biri yaklaşı 40 dakika olmak üzere toplam 80 dakika uygulanmıştır. Bu çalışma kapsamında "Hoverland" oyunu içerisinde yer alan doğal sayılar ünitesindeki deste, düzine, nesne sayısını tahmin etme ve ileriye doğru birer ve ikişer ritmik sayma konu alanları, uzamsal ilişkiler ünitesinde yer alan yer, yön ve hareket belirtme konu alanları ve geometrik örüntüler ünitesinde yer alan geometrik örüntüde verilmeyeni bulma konu alanları yer almıştır.

"Hoverland" mobil matematik oyunu ilköğretim öğrencilerini hedefleyen dijital bir oyundur. Oyun akı1lı telefonlarda ya da tabletlerde oynanabilmektedir. Oyun kasaba olarak adlandırılan açık bir dünya içerisinde kaykay üzerinde hareket eden bir "hoverboy" ya da "hovergirl" karakterinin macerasını konu almaktadır. İlgili karakter kaykay ile oyun dünyası içinde gezinirken farklı kişilerle iletişime geçmekte ve o kişiler tarafından verilen görevleri yerine getirmeye çalışmaktadır (Şekil 1). 


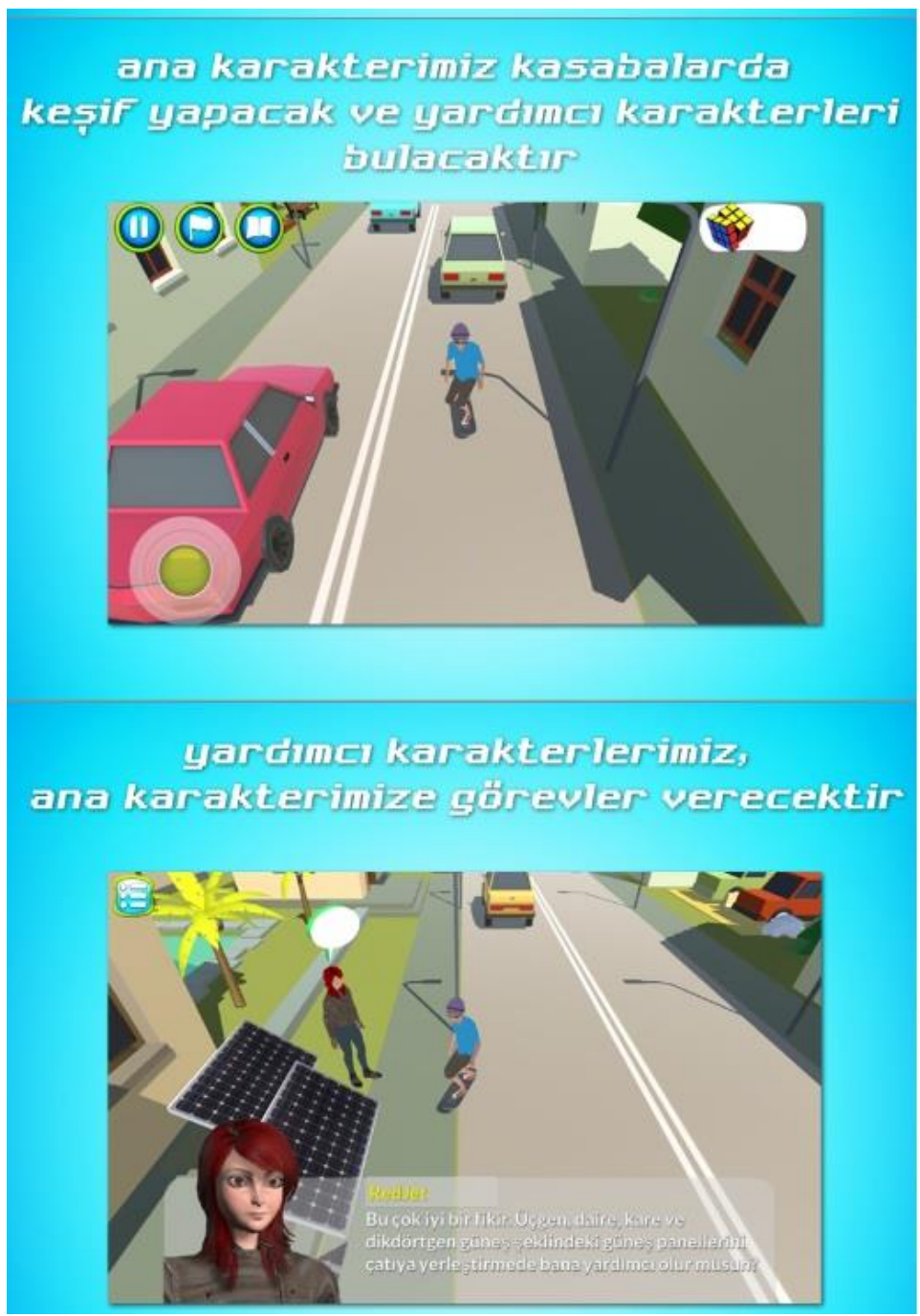

Şekil 1. Mobil Oyun İ̧̧erisindeki Karakterlerin Yerleşimi

İlgili görevler küçük oyunlar olarak oyuncuya sunulmaktadır. Oyuncu her bir küçük oyun içerisinde farklı oyun mekanikleri ile (doğru sayıda meyve seçme, küpleri sırasına göre yerleştirme, doğru şeklin içerisinden geçme vb.) ilköğretim matematik müfredatında yer alan farklı konu ve becerileri oyun içerisinde uygulama şansı bulmaktadır. Her bir küçük oyun içerisinde oyunlaştırmayı da desteklemek amacı ile farklı level (düzeyler), zaman kısıtlamaları ve puan kazanımları gibi bileşenler yer almaktadır. Örneğin, güneş panellerini çatıya yerleştirme görevinde oyuncunun üçgen, dikdörtgen ve kare şeklindeki panelleri oyun içerisinde belirli bir zamanda doğru ve eksiksiz eşleştirerek yerleştirmesi gerekmektedir. Oyuncu doğru ve eksiksiz yerleştirme süresi ve deneme sayısına bağlı olarak yıldız kazanmaktadır. Bu oyun içerisinde desteklenmesi hedeflenen beceri, ilköğretim matematik geometrik cisim ve şekiller ünitesinde yer alan geometrik şekilleri sınıflandırmadır (Şekil 2).

Genel olarak "Hoverland" oyunu içerisinde yer alan konu alanları şu şekildedir:

- Doğal Sayılar Ünitesi - Deste

- Doğal Sayılar ünitesi - Düzine

- Doğal Sayılar Ünitesi - Nesne sayısını tahmin etme

- Doğal Sayılar Ünitesi - İleriye doğru birer ritmik sayma

- Doğal Sayılar Ünitesi - İleriye doğru ikişer ritmik sayma

- Doğal Sayılarla Toplama İşlemi ünitesi

- Geometrik Cisim ve Şekiller ünitesi - geometrik şekilleri sınıflandırma

- Uzamsal İlişkiler ünitesi - yer, yön ve hareket belirtme

- Geometrik Örüntüler Ünitesi - Geometrik örüntüde verilmeyeni bulma 

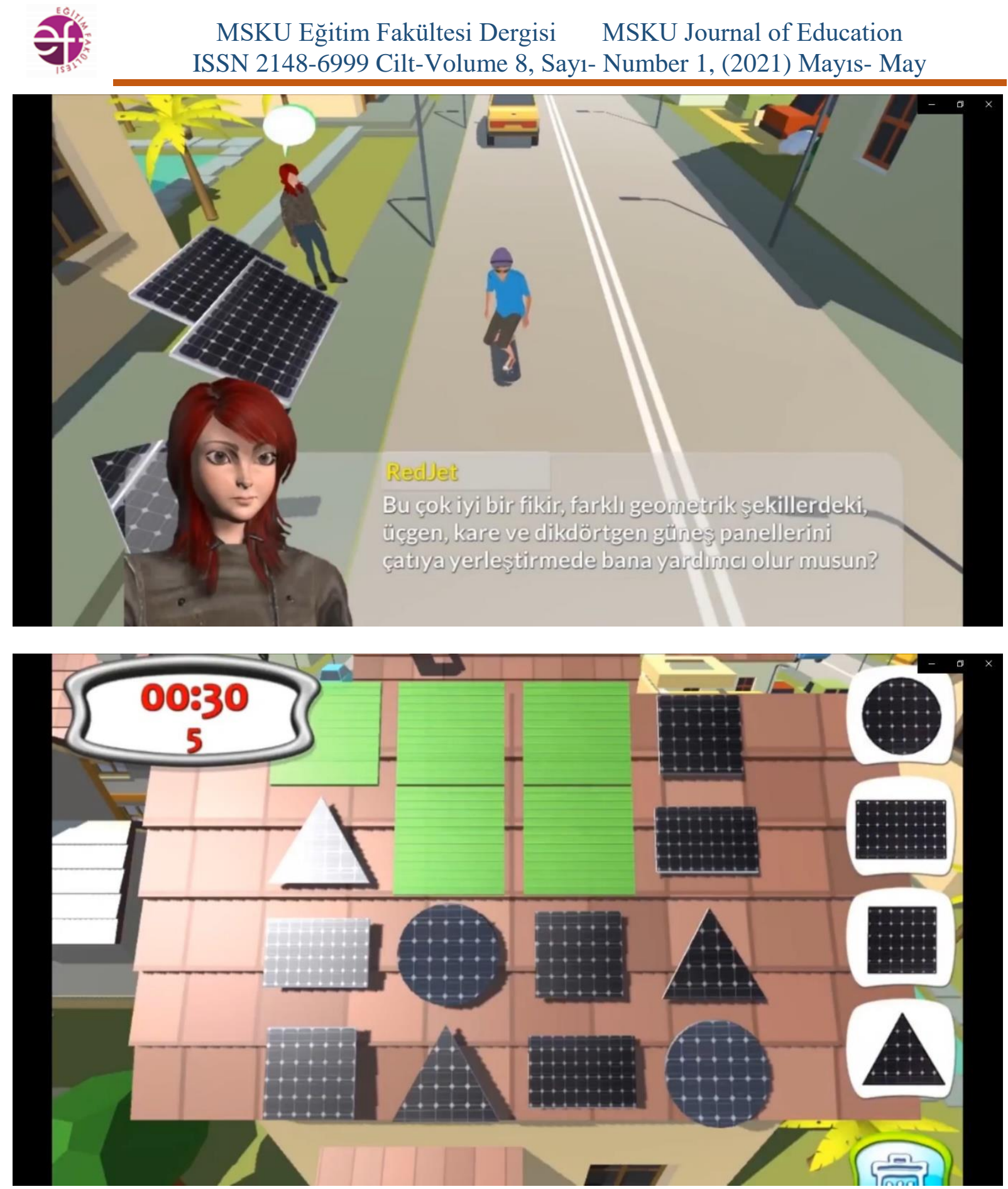

Şekil 2. Güneş Panellerini Çatıya Yerleştirme Oyunu

Araştırma verilerinin toplanmasında kullanılan ilk nitel veri toplama aracı gözlem olmuştur. Araştırmacı her iki farklı dersteki oyunlaştırma sürecini baştan sona gözlemleyerek öğrencilerin ve öğretmenin davranış ve söylemleri hakkında notlar almıştır. Araştırma kapsamında kullanılan gözlem türü yapılandırılmamış gözlemdir. Yapılandırılmamış gözlem, durum çalışmalarının temel veri toplama tekniklerinden biri olarak kabul edilmekte ve araştırmacının katılımcı gözlemci olarak yer aldığ bir süreci temsil etmektedir (Çengelci, 2010). Araştırma verilerinin toplanmasında kullanılan diğer bir veri toplama aracı ise yarı yapılandırılmış görüşme olmuştur. Yarı yapılandırılmış görüşmede araştırmacı soruları bir görüşme protokolü şeklinde hazırlamakta ve görüşme esnasında önceden hazırlanmış protokolü daha derinlemesine cevaplar alabilmek maksadıyla esnetip, ek sorularla zenginleştirebilmektedir (Türnüklü, 2000). Bu çalışma kapsamında öğrenci ve öğretmenle gerçekleştirilecek yarı yapılandırılmış görüşmeler için iki form hazırlanmıştır. Formların içeriğinde yer alan sorular literatür destekli olarak hazırlanmış ve iki uzman tarafından gözden geçirilerek son hali elde edilmiştir. Uzmanlardan her ikisi de dijital oyun tasarımı bölümünde görev almakta olup, birinin daha önceden öğretmenlik deneyimi de bulunmaktadır. Öğrenciler için oluşturulmuş görüşme formunda 
oyunlaştırma sürecinin işleyişine, oyunlaştırma yapmada kullanılan dijital mobil oyunun etkililiğine ve matematik içeriğinin uygunluğuna yönelik sorular yer almıştır. Görüşme formunda yer alan örnek sorular şu şekildedir:

- Hoverland mobil matematik oyununu sınıf içinde oynamak senin için ne gibi değişiklikler yarattı?

- Hoverland matematik oyununda beğendiğin özellikler nelerdir?

- Hoverland matematik oyununda beğenmediğin özellikler nelerdir?

- Matematik konularını sınıf içi oyunlaştırmada görmek ve işlemek hakkında neler düşünüyorsun?

Öğretmen için oluşturulmuş görüşme formunda ise oyunlaştırmanın sınıf içinde uygulanmasına, eğitsel mobil oyunun oyunlaştırma içindeki rolüne ve pedagojik açıdan etkilerine dair sorular yer almıştır. Görüşme formunda yer alan örnek sorular şu şekildedir:

- Sinıf içi oyunlaştırma hakkında ne düşünüyorsunuz?

- Hoverland eğitsel mobil matematik oyunu ile sınıf içi oyunlaştırmada beğendiğiniz özellikler nelerdir?

- Hoverland eğitsel mobil matematik oyunu ile sınıf içi oyunlaştırmada sizi zorlayan ve olumsuz gördüğünüz özellikler nelerdir?

- Pedagojik açıdan sınıf içi oyunlaştırmanın avantajları ve dezavantajları neler olabilir?

- Matematik konularını öğretmede sınıf içi oyunlaştırma faydalı olabilir mi? Neden?

\section{Verilerin Analizi}

Araştırma verilerinin analizinde nitel veri analizi yöntemlerinden betimsel analiz ve içerik analizi kullanılmıştır. Gözlem yoluyla elde edilen verilerin analizinde betimsel analiz uygulanmıştır. Betimsel analiz, elde edilen verilerin özetlenmiş ve yorumlanmış olarak aktarılmasına imkân tanıyan bir nitel analiz yöntemidir (Özen ve Hendekçi, 2016). Betimsel analizde araştırmacı öncelikle sınıf içi oyunlaştırma süresince aldığı notları düzenli metinler haline getirmiştir. Daha sonra, düzenli metinleri araştırma sorusunu göz önünde bulundurarak incelemiş ve analiz etmiştir. Son olarak da analiz edilen metinden anlamlı olan gözlem verileri bulgular olarak rapor edilmiştir. Görüşme yoluyla elde edilen verilerin analizinde ise içerik analizi uygulanmıştır. İçerik analizi, yazılı metinlerin sistematik biçimde analizine imkân tanımaktadır (Fraenkel ve Wallen, 2006). Bogdan ve Biklen (2007) içerik analizinde veri toplama araçlarıyla elde edilen verilerin öncelikle analize hazır hale getirilecek şekilde bloklara ayrılması gerektiğini, daha sonra her bir bloğun kodlanarak temaların ortaya çıkartılmasını önermiştir. $\mathrm{Bu}$ öneri doğrultusunda, çalışma kapsamında yarı yapılandırılmış görüşme sonucunda elde edilen metinler kodlanmış, ortaya çıkan kodlar ortak özellikleri doğrultusunda temalar altında birleştirilerek sunulmuştur. İçerik analizi sonucu elde edilen kodların sunumunda destekleyici olarak öğrenci ve öğretmenlerin ifadeleri metin içinde kullanılmıştır. Öğrenciler ile ilgili ifadelerin sunumunda öğrenciyi tanımlamak için "Ö" harfi ve sıra numarası kullanılmıştır (örn; Ö3, Ö8 vb.). Benzer şekilde, sınıf öğretmeni ile ilgili ifadelerin sunumunda öğretmeni tanımlamak için "SÖ" kullanılmıştır.

\section{Geçerlik ve Güvenirlik}

Bogdan ve Biklen (2007)'e göre çeşitlendirilmiş veri kaynakları araştırılan konunun derinlemesine analizine imkân vermesi açısından önemli bir güvenirlik ve geçerlik stratejisidir. Bu strateji doğrultusunda, bu çalışma kapsamında da gözlem ve görüşme olmak üzere çeşitlendirilmiş veri toplama yöntemleri kullanılmıştır. Denetleme yolu, bir geçerlik ve güvenirlik stratejisi olarak nitel araştırma sürecinde gerçekleşen tüm prosedürler ile veri toplama ve veri analizi gibi tüm yöntemsel süreçlerin detaylı ve özenli bir şekilde sunulmasıdır (Başkale, 2016). Bu araştırma kapsamında tüm süreç açı bir şekilde aktarılmış, içerik analiziyle elde edilen kodların sunumunda ham metinlere referanslar verilmiş ve ilgili görseller sunularak sınıf içi uygulama örnekleri gösterilmiştir. Uzman incelemesi, araştırmanın farklı boyutlarıyla incelenmesi amacıyla araştırma konusu hakkında bilgiye sahip olan kişiler tarafindan gerçekleştirilen bir güvenirlik ve geçerlik stratejisidir (Başkale, 2016). Bu çalışmada yarı yapılandırılmış görüşmelerde kullanılacak formların oluşturulmasında iki alan uzmanının önerileri dikkate alınmıştır. Ayrıca, betimsel ve içerik analiz süreci ve içerik analizi sonucu ortaya çıkan kod ve temaların uygunluğu, aynı uzmanlar tarafından gözden geçirilmiştir. Marshall ve Rossman (2011)'a göre kodlayıcılar arası güvenirlik, aynı metinden elde edilen kodların farklı kodlayıcılar açısından tutarlılık göstermesidir. Miles ve Huberman (1994)'e göre kodlayıcılar arası güvenirlik skoru en az 0.80 olmalıdır. Bu araştırmada hesaplanan skor 0.87 olmuştur. 


\section{Bulgular}

$\mathrm{Bu}$ bölümde araştırma soruları temel alınarak bulgular sunulmuştur. $\mathrm{Bu}$ kapsamda, öncelikle yapılandırılmamış gözlem yoluyla elde edilmiş eğitsel mobil matematik oyunu ile gerçekleştirilen sınıf içi oyunlaştırmaya ilișkin öğretmen ve öğrencilerin deneyimleri sunulmuștur. Sonraki bölümde ise yarı yapılandırılmış görüşme ile elde edilen öğretmen ve öğrencilerin sınıf içi oyunlaştırmaya ait görüşleri aktarılmıştır.

\section{Eğitsel Mobil Matematik Oyunu ile Gerçekleştirilen Sınıf İçi Oyunlaştırmaya ilişkin Öğretmen ve Öğrencilerin Deneyimleri Nasıldır?}

Yapılandırılmamış gözlem yoluyla elde edilen verilerin betimsel analizi sonucunda ortaya çıkan bulgulara göre öğrencilerin her biri, dijital oyunlaştırma içerisinde eğlenceli bir şekilde gezinmişlerdir. Öğrenciler özellikle oyun içinde kaykay üzerindeki karakteri kendileriyle özdeşleştirmektedir. Dolayısıyla oyun içi karakterlerin öğrencilerin yaşına uygun tasarlanması önemlidir. Öğrenciler düz görseller yerine daha hareketli animasyonları tercih etmektedir. Örneğin, birkaç öğrenci oyun içerisinde karşısına çıkan hareketsiz bir karakteri üzerine eliyle dokunarak hareket ettirmeye çalışmıştır. Öğrenciler oyun içerisinde daha fazla yönlendirmeye ihtiyaç duymaktadır. Örneğin, üç öğrenci oyunu anlama noktasında bazı yerlerde tereddüt yaşamışlardır. Karakterin hangi yöne gideceğinin ve hangi göreve nasıl ulaşacağının net olarak ifade edilmesi gerekmektedir. Oyun içerisinde öğrencilerin her bir hamlesine doğru ve yapılandırılmış geri bildirim verilmesi gerekmektedir. Örneğin, öğrenci kaykay üzerinde hareket eden karakteri yönlendirirken, karşısına çıkacağı karakterle nasıl etkileşim kuracağı konusunda kararsız kalmıştır. Bu nedenle oyun içi farklı karakterler ile konuşma esnasında konuşmanın başlayacağını ifade eden diyalog balonunu görmesi gerekmektedir. Öğrenciler özellikle dijital oyunlaştırma temelinde büyük ve tek bir oyun yerine küçük küçük farklı seçenekli oyunlara daha fazla eğilim göstermiştir. Bu nedenle, farklı ünitelerdeki farklı konulara odaklanan küçük mobil oyunlar öğrencileri daha fazla tatmin etmektedir. Bir diğer önemli bulgu, öğrencilerin oyun içerisinde "challenge" adı verilen zorluk seviyeleri ile oyun akışı içinde kalmalarıdır. Bu nedenle, hazırlanan her bir mobil oyun dünyasında farklı seviyeler (level) verilmesi daha uygun olacaktır.

Oyunlaştırma sürecine ilişkin öğrenciler oyun sonucunda kazandıkları rozetleri saklama ve arkadaşlarıyla paylaşma eğiliminde olmuştur. "Hoverland" oyun dünyası içerisinde farklı oyunlardan farklı rozetler elde edilebilme imkânı öğrencilerde daha fazla oyun oynama isteği doğurmuştur. $\mathrm{Bu}$ bulgudan hareketle oyunlaştırma unsurlarının öğrencileri motive ettiği söylenebilir. Her bir öğrencinin akıllı tahtada oyunu oynaması, sınıf içerisindeki diğer öğrencilerin de ilgisini tahtaya çekmeye yardımcı olmuştur. Örneğin, doğal sayılar ünitesinde yer alan deste ve düzine kavramlarının işlendiği oyunda tahtadaki öğrenci doğru sayıdaki meyveleri sepetlere yerleştirmeye çalışırken, onu izleyen arkadaşları da öğrencinin doğru ya da yanlış hamlelerine tepkide bulunmuştur. Dolayısıyla, sınıf içi oyunlaştırmada tüm öğrencilerin ilgisi ve dikkati oyunu bizzat oynayan öğrencide toplanabilmiştir. Özellikle anlaşılması zor olabilecek matematik konularının bu şekilde oyunlaştırma ile verilmesi, tüm sınıfın sürece dâhil edilebilmesi açısından önemli görülebilir. Oyunlaştırmanın sınıf içinde kullanılmasının bir diğer yöntemi gruplar şeklinde olmuştur. Üçlü ya da dörtlü öğrenci grupları kendilerine verilen tabletler ile "Hoverland" oyununu oynamışlar ve oyun içindeki üretici, yol gösterici, uygulayıcı ve aktarıcı rollerine göre oyunları tamamlamışlardır. Daha sonra diğer arkadaşlarına da oyun içindeki yaptıkları hamleleri ve oyunun akışını sunmuşlardır. Tablet ile oyunu oynayan öğrencilerden örnek bir grup Şekil 3'de gösterilmektedir. Grup ile oynama sürecinde öğrencilerin daha fazla sorumluluk aldıkları ve grup içi etkileşime daha çok önem verdikleri söylenebilir.

Sınıf öğretmeni eğitsel mobil matematik oyunu "Hoverland" ile yapılan sınıf içi oyunlaştırmada önemli bir role sahiptir. Tüm sürecin yönetilmesinde, öğrencilerin oyunun heyecanıyla birlikte içeriğe odaklanabilmesinde ve oyun zamanlarının dengeli bir şekilde ayarlanmasında sınıf öğretmeni süreci yönetmiş̧tir. Sınıf içi oyunlaştırmada öğretmenin olumlu geri bildirimleri öğrencilerin motivasyonlarının sürdürülmesinde etkili olmuştur. Öğretmen her öğrencinin oyunu tahtada oynamasını sağlamıştır. Bununla birlikte her öğrencinin oyun sonunda kazandığg yıldızları not etmiş ve yıldız sayısına bağlı olarak matematik dehası, dört işlem uzmanı, geometri kraliçesi gibi statüler belirlemiştir. Oyunlaştırma sürecine tüm sınıfın dâhil olması ve aktif olarak oyun ile ilişkili içeriğe odaklanılması önem arz etmektedir. Dolayısıyla, öğretmen sınıf içi katılımı maksimum tutmaya çalışmıştır. Sınıf içi oyunlaştırmada karşılaşılan en büyük zorluk sınıf yönetimi olmuştur. Oyunlaştırma esnasında her 
öğrencinin müdahale etme isteği, oyuna dair ikazlar ve sırasını beklemek istemeyen öğrenciler gibi aksiyonlar oyunlaştırma sürecinde ortaya çıkan dezavantajlar olarak görülebilir.

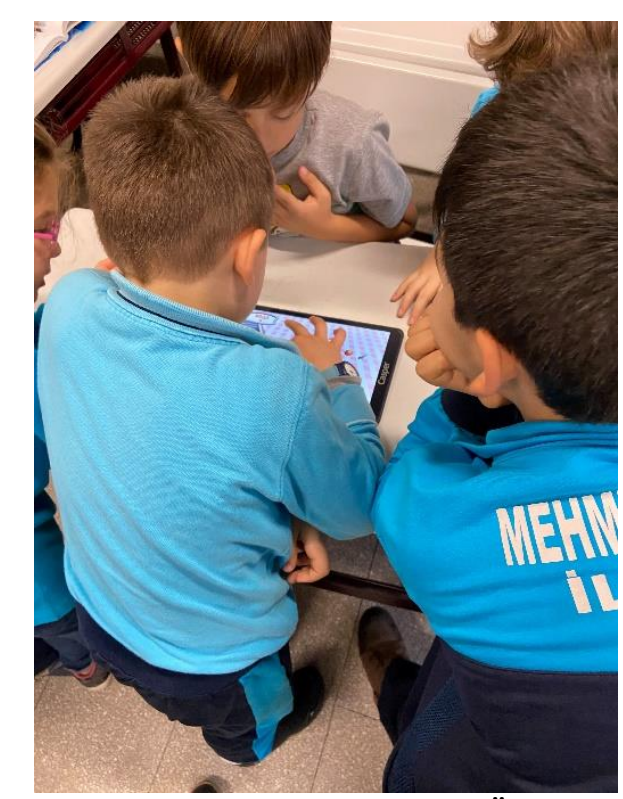

Şekil 3. Tablet ile Oyunu Oynayan Öğrenci Grubu

\section{Eğitsel Mobil Matematik Oyunu ile Gerçekleştirilen Sınıf İçi Oyunlaştırmaya ilişkin Öğretmen ve Öğrencilerin Görüşleri Nelerdir?}

On beş öğrenci ile gerçekleştirilen yarı yapılandırılmış görüşmelerin içerik analizi sonucunda özellikle iki tema ortaya çıkmıştır. Bu temalar, oyunlaştırmada kullanılan eğitsel mobil matematik oyununa ilişkin "tasarım" ve "içerik" temalarıdır. Temalar ve açıklamaları altta detaylı verilmiştir.

\section{Tasarım}

\section{Tablo 3}

Tasarım Temasına Illişkin Kodlar ve Frekanslar

\begin{tabular}{lc}
\hline Tasarım & $\mathrm{f}$ \\
\hline Erkek ve kız öğrenciler için her iki cinste de seçebilecekleri ana karakter oyunlar içerisinde & 10 \\
sunulmalıdır. & 11 \\
Öğrencilerin ilgisini çekecek animasyonlu görsellerin kullanımına daha fazla ağırlık & \\
verilmelidir. & 12 \\
Oyun içi karakterler ve görseller dinamik olmalıdır. & 9 \\
Oyun içerisinde yer alan tüm butonlar ya da tasarım öğeleri aktif ve çalışıyor olmalıdır. & \\
\hline
\end{tabular}

Tasarım temasına ilişkin kodlar Tablo 3'de özet olarak gösterilmiştir. Oyunlaştırmada kullanılan eğitsel mobil matematik oyunu "Hoverland" tasarımına ilişkin ilk bulgu oyun içindeki seçilebilecek karakterin her iki cinste de verilmesi gerektiğidir. Oyun sunumunda hem k1z hem de erkek kaykay karakteri gösterilirken; oyun içinde sadece erkek karakteri kullanılmaktadır. 15 öğrenciden 10’u sadece erkek değil kız kaykay karakterini de seçmek istediklerini belirtmişlerdir. Tasarıma ilişkin bir diğer bulgu, animasyonlu görsellere oyun içinde daha fazla yer verilmesi gerekliliğidir. Örneğin, bazı öğrenciler bu durumu şu şekilde ifade etmiștir:

"Kaykayla kaymayı çok sevdim. Sepetteki meyveleri yerleştirmeye çalıştım ama biraz sıkıldım. Orman içinde böceklerden kaçmaya çalıştığımız oyun çok eğlenceliydi" (Ö5).

Tasarıma ilişkin bulgulardan bir diğeri oyun içi karakter ve görsellerin dinamik olmasıdır. Mobil oyun dünyası içerisinde 15 öğrencinin 12'si hareketsiz duran görsellere dokunmalarına rağmen hareket etmediklerini ifade etmiştir. Bu konuya ilişkin bir öğrencinin ifadesi şu şekilde olmuştur:

"Kaykayla gezerken biri karşıma çıktı. Ben onunla konuştum ama o hiç hareket etmedi. Dokunduğumda o da konuşacak sandım ama olmadı" (Ö7). 
Oyunlaştırma içerisinde kullanılan eğitsel mobil matematik oyununun tasarımına ilişkin son bulgu, oyun içerisinde yer alan tüm butonların ya da tasarım öğelerinin aktif ve çalışıyor olması gerekliliğidir. Gerçekleştirilen yarı yapılandırılmış görüşmede 15 öğrencinin 9'u bu durumu ifade etmiştir. Örneğin;

"Kaykayımla saylların üzerinden geçtim ve bitirdim fakat ileri butonuna bastım olmadı. Oyun kendisi ilerledi" (Ö2).

"Ben tıklyyorum konuşmayı beklemeden oyuna başlamak için ama olmuyor. İlla konuşmanın bitmesini bekledim”(Ö6).

\section{İçerik}

Tablo 4

İçerik Temasına İlişkin Kodlar ve Frekanslar

\begin{tabular}{lc}
\hline İçerik & $\mathrm{f}$ \\
\hline Oyun içerisinde kavram karmaşası olmamalıdır. & 13 \\
Matematik kazanımlarını destekleyecek küçük oyunlara daha fazla yer verilmelidir. & 9 \\
Oyun içi seviyeler oluşturulmalı ve bu seviyeler basitten zora doğru sunulmalıdır. & 11 \\
\hline
\end{tabular}

İçerik temasına ilişkin kodlar Tablo 4'de özet olarak gösterilmiştir. Oyunlaştırmada kullanılan eğitsel mobil matematik oyunu "Hoverland" içeriğine ilişkin ilk bulgu oyun içerisinde kavram karmaşasının önüne geçilmesi gerekliliğidir. Gerçek hayattan örneği verilen bir objenin hangi geometrik şekle benzediğinin bulunmaya çalışıldığı bir oyunda öğrenciler ilgili objenin kare mi dikdörtgen mi olduğunu kolayca ayırt edebiliyor olmalıdır. Yarı yapılandırılmış görüşmeye katılan 15 öğrencinin 13’ü bu durumu vurgulamıştır. Öğrencilerin buna ilişkin tepkileri şu şekilde olmuştur:

"Hoverboy ile resimleri seçmeye çalış̧ım, doğru yaptığımı sandım ama kare değilmiş. Çok kare gibiydi, orada kafam karıștı" (Ö14).

"Bayrak resmi vardl, onu eşleştirmeye çalıştım. İki şekle de çok benzedi ama yanlış yapmışım” (Ö9).

İçeriğe ilişkin bulgulardan bir diğeri, öğrencilere ilgili matematik ünitelerindeki kazanımları vermek üzere daha fazla küçük mobil oyun sunulması ve oyunlaştırma sürecinde ilgili evrene dâhil edilmesidir. Görüşme yapılan 15 öğrenciden 9'u oyunlaştırma içinde yer alan küçük oyunları çok sevdiklerini ve her oyunda farklı heyecan yaşadıklarını belirtmiştir. Örneğin;

"Ritmik sayma oyununda doğru saylların üzerinden giderek oyunu kazandım. Başka oyunda doğru sayıda meyveleri sepete yerleştirdim ve manav görevini bitirdim. Oyunları çok sevdim" (Ö9).

"Ritmik sayma oyununda çok eğlendim. Yanlıs yaptım ama 3 hakkım vardl ve sonunda geçtim. Oyun bittiğinde hoverboy kaykaylyla uçtu, çok beğendim” (Ö6).

İçeriğe ilişkin son bulgu oyun içi seviyelerin varlığı ve basitten zora doğru sunulması gerekliliğidir. Örneğin, ilk oyunda birer ritmik sayma oyun içerisinde işlenmiş, bir sonraki seviyede ise ikişer ritmik sayma verilmiştir. Öğrenciler çoğunlukla ilk seviyede oyunu anladıklarını ve diğer seviyeleri daha kolay geçebildiklerini belirtmiştir. Örneğin;

"Ritmik sayma oyununda önce birli sayarak hoverboy doğru sayllardan geçti ve oyunu bitirdi. İlk başta zorlandım ama sonra anladım ve tüm hepsini kolaylıkla geçtim" (Ö7).

"Sepet oyununda başta az meyve vardı ve saylları doğru yaptım ama en sonunda biraz karışılk oldu. Yine de son hakkimda oyunu bitirdim" (Ö5).

\section{Oyunlaştırma süreci}

Sınıf öğretmeni ile gerçekleştirilen yarı yapılandırılmış görüşmenin içerik analizi sonucunda oyunlaştırma süreci ana tema olarak ortaya çıkmıştır. İlgili tema ve açıklamaları altta detaylı verilmiştir. Oyunlaştırma sürecine ilişkin ilk bulgu dijital oyunlaştırma sürecinde sınıf içerisinde oyunların akıllı tahtaya yansıtılarak grupça oynanmasıdır. Sınıf öğretmenine göre her öğrencinin katılımı oyunlaştırmanın etkinliği açısından önemlidir. Bir diğer bulgu oyunlaştırma yaparken öğretmenin aktif rol alması gerekliliğidir. Sınıf öğretmeni bu durumu şu şekilde açıklamıştır:

“...Oyunlaştırılan matematik konularında öğretmen hızlı müdahale etmeli ve öğrencilerin zorlandıkları ya da sıklldıları noktada süreci zenginleştirmelidir” (SÖ).

Diğer bir bulgu ise oyunlaştırma yaparken öğrencilerin konuya dönük motivasyonlarının üst seviyede tutulmasıdır. Sınıf öğretmeninin bu bulguya ilişkin ifadesi şu şekildedir:

“...Öğrencilerin oyunlara motivasyonu üst noktadadır fakat oyunlaştırmada aynı anda her ögrrencinin oyunu bizzat oynamamasına karşın diğer öğrenciler de sürekli süreç içinde aktif olmalıdır” (SÖ). 
Oyunlaştırma sürecine ilişkin diğer bir bulgu oyunlaştırma içerisinde öğrencinin oyunda elde ettiği başarı hissini tatmasıdır. Sınıf öğretmenine göre öğrencinin yanlış yapması durumunda doğrusu gösterilmeli, hatalı olduğu hissi öğrenciye yaşatılmamalıdır. Bir diğer bulguya göre, oyunlaştırmada teknik altyapının ve oyunların akıllı tahtaya yansıtılabiliyor olmasının önemi büyüktür. Sınıf öğretmeni teknik zorlukların oyunlaştırmanın başarısını düşürebileceğini belirtmiştir. Oyunlaştırma sürecine ilişkin son bulgu öğretmenlerin dijital oyunlaştırmayı etkili kullanabilmeleri için temel seviyede bile olsa teknoloji okuryazarı olması gerektiğidir. Sınıf öğretmeni bu durumu şu şekilde açıklamıştır:

“...Teknoloji okur yazarı olmayan ögretmen için oyunlaştırma sürecinde öğrencilerin ihtiyaçlarını ve motivasyonlarını anlamak kolay değildir" (SÖ).

Oyunlaştırma süreci temasına ilişsin kodlar Tablo 5'de özet olarak gösterilmiştir.

Tablo 5

Oyunlaştırma Süreci Temasina İlişkin Kodlar

\begin{tabular}{l}
\hline Oyunlaştırma süreci \\
\hline Dijital oyunlaştırma sürecinde sınıf içerisinde oyunlar akıllı tahtaya yansıtılarak grupça oynanmalıdır. \\
Oyunlaştırma yaparken öğretmen aktif rol almalıdır. \\
Oyunlaştırma yaparken öğrencilerin konuya dönük motivasyonları üst seviyede tutulmalıdır. \\
Oyunlaştırma içerisinde öğrenci oyunda elde ettiği başarı hissini tatmalıdır. \\
Teknik alt yapı oyunlaştırma için hazır olmalıdır. \\
Temel seviyede bile olsa öğretmen teknoloji okuryazarı olmalıdır.
\end{tabular}

\section{Tartışma ve Sonuç}

Oyunlaştırma son zamanlarda özellikle eğitim alanında pek çok araştırmanın odak noktasını oluşturmaktadır. Bu çalışmanın amacı da öğretmen ve öğrencilerin eğitsel mobil matematik oyunu kullanılarak sınıf içinde yapılacak oyunlaştırma uygulamasına ilişkin deneyimlerini ve görüşlerini ortaya çıkarmaktır. Yapılandırılmamış gözlem sonucu elde edilen bulgulardan birine göre dijital oyunlaştırma içerisinde öğrenciler eğlenceli bir şekilde gezinmişlerdir. Bu bulgu, Bozkurt ve GençKumtepe'nin (2014) oyunlaştırmanın öğrencilere eğlenceli ve ilgi çekici tecrübeler yaşamasına izin verdiği bulgusuyla paralellik göstermektedir. Benzer şekilde Hamari ve diğ. (2014) oyunlaştırmanın, öğrenme hedeflerine ulaşmada eğlenceli bir süreç oluşturduğunu ortaya koymuştur. Gözlem sonucu elde edilen bulgulardan bir diğeri, dijital oyunlaştırmada kullanılan mobil oyunda öğrencilerin düz görseller yerine hareketli animasyonları tercih etmesidir. Bu noktadan hareketle oyunlaştırma yapmak için kullanılacak mobil oyunlarda "puzzle" vb. oyunlar yerine karakter ve aksiyon temelli platform oyunlarının ön planda tutulması gerektiği söylenebilir. Gözlem sonucu ortaya çıkan bir diğer bulgu oyunlaştırma sürecinde ve oyun içerisinde öğrencilerin her bir hamlesine doğru ve yapılandırılmış geri bildirim verilmesi gerekliliğidir. Çağlar ve Kocadere (2015)'e göre oyunlaştırma bileşenlerinin her biri aynı zamanda geri bildirim olarak değerlendirilmekte ve bu geri bildirimlerin sık sık ve anında verilmesi önemli görülmektedir. Benzer şekilde Meşe ve Dursun (2018) oyunlaştırmada verilen hızlı bildirimlerin öğrenciler tarafından ilgi çekici bulunduğunu belirtmiştir. Domínguez ve diğ. (2013) de oyunlaştırma deneyimine katılan öğrencilerin uygulamalı ödevlerde daha yüksek puanlar almasında anlamlı geri bildirimlerin destekleyici rolünü vurgulamıştır. Yapılandırılmamış gözlem sonucu elde edilen bulgulardan bir diğeri öğrencilerin oyun içerisinde "challenge" adı verilen zorluk seviyeleri ile oyun akışı içinde kalmalarıdır. Oyunlaştırma içinde sunulan mobil oyunda öncelikli olarak kolay seviyelerin sunulması ve gittikçe zorlaşması öğrencilerin sürece adapte olmasında kolaylık sağlayabilir. Bu bulguyu destekleyecek şekilde Çağlar ve Kocadere (2015)'e göre oyun başlangıçlarında daha kolay seviyeler sunulmalı ve ilerledikçe seviyelerin düzeyi artırılmalıdır. Bu bulgu ayrıca González ve Area (2013)'nın eğitsel materyallerde kullanılabilecek, kullanıcı deneyimine veya uzmanlaşmasına bağlı farklı oyun içi düzeyler veya bölümler önerisini desteklemektedir.

Yapılandırılmamış gözlem sonucu elde edilen önemli bulgulardan biri oyunlaştırma sürecinde öğrencilerin rozetler kazanması ve bu rozetleri saklama eğiliminde olmalarıdır. Ayrıca, öğrenciler grupça oynadıkları ve sınıf içi oyunlaştırmaya katıldıkları süreçte de arkadaşlarıyla grup içi etkileşimi yüksek seviyede tutmuşlar ve rozetleri kazanmaya çalışmışlardır. Sınıf öğretmeni de bu noktada öğrencileri yönlendirmiş ve kazanılan yıldızları ve rozetleri not ederek farklı olumlu unvanlar vermiştir. 
Bu rozetlerin ve yıldızların özellikle hem iş birliğini hem de rekabeti sağlayarak oyunlaştırma sürecini desteklediği söylenebilir. Literatürdeki çalışmalarda da ödüllendirme sisteminin oyunlaştırma sürecinde öğrencilerin ilgisini arttırdığı ortaya konulmuştur. Örneğin, Sarı ve Altun (2016) tarafindan gerçekleştirilen araştırma sonucuna göre oyunlaştırma içerisinde öğrencilerin kazandıkları yıldız ve rozetler öğrencilerin motivasyonunu ve ilgisini artırmıştır. Benzer olarak, Karayılan ve diğ. (2018) araştırmalarında liderlik tablosu ve ödül gibi oyunlaştırma bileşenlerinin kullanıldığı deney grubunda öğrenci puanlarının kontrol grubuna göre daha yüksek çıktığını bulmuşlardır. Aynı şekilde Meşe ve Dursun (2018) de ödül ve rozet gibi oyunlaştırma bileşenlerinin öğrencileri daha mutlu ve eğlenceli hale getirdiğini ortaya koymuştur. González ve Area (2013)'nın oyun bileşenleri önerilerinde de rozet ve yıldız gibi koleksiyonlar oyuncuların biriktirme özelliğini vurgulayarak eğitsel oyunlaştırma sürecini zenginleştirmektedir. Bununla birlikte lider tahtaları ya da sosyal bileşenler rekabeti ve etkileşimi artırarak öğrencilerin oyunlaştırma süreci içindeki deneyimini iyileştirmektedir (González ve Area, 2013).

Yapılandırılmamış gözlem sonucu sınıf öğretmeninin oyunlaştırma sürecindeki deneyimine ilişkin en önemli bulgu sınıf yönetimi zorluğu olmuştur. Oyunlaştırma esnasında her öğrencinin müdahale etme isteği, oyuna dair ikazlar ve sırasını beklemek istemeyen öğrenciler gibi aksiyonlar oyunlaştırma sürecinde ortaya çıkan dezavantajlar olarak görülebilir. Sınıf içi oyunlaştırmada sınıf öğretmeninin tüm süreci yönetme ve aynı zamanda her bir öğrenciyi süreç içerisinde aktif tutma sorumluluğu vardır. Bu nedenle, sınıf yönetimi öğretmeni zorlamakla birlikte özellikle ilköğretim öğrencileri olması sebebiyle tüm süreci organize etmede aksaklıklara yol açabilmektedir. Sınıf içi oyunlaştırma sürecinde sınıf yönetimi organizasyonunun mutlaka önceden ele alınması gerekmektedir.

Öğrenciler ile gerçekleştirilen yarı yapılandırılmış görüşmeler sonucunda oyunlaştırmada kullanılan mobil oyuna ilişkin tasarım ve içerik temasında birleşen bulgular ortaya çıkmıştır. Tasarıma ilişkin ilk bulgu oyun içindeki seçilebilecek karakterin her iki cinste de verilmesi gerektiğidir. Öğrenciler oyun içinde yönetecekleri karakteri kendileri seçme eğiliminde olmakta ve hem kız hem de erkek karakteri görmek istemektedir. Karaşahinoğlu (2018) bu bulguya benzer şekilde büyük çocuklarda cinsiyet farklılıklarının ön plana çıkmaya başladığını ve uygulamaların hem kız hem de erkek çocuklarına hitap etmesi gerektiğini belirtmiştir. Aynı şekilde Deterding ve diğ. (2011) oyunlarda farklı cinsiyet gruplarını da içine alabilecek farklı oyun oynama stillerine uygunluğun önemini vurgulamıştır. Tasarıma ilişkin diğer bulgular oyun içi animasyonların daha fazla yer alması ve bu animasyonların dinamik bir şekilde sunulmasıdır. Karaşahinoğlu (2018)'na göre de sekiz yaş ve civarı öğrenciler oyunlar içerisinde karmaşı ve ileri düzey görseller ve tasarımlar beklemektedir. Deterding ve diğg. (2011)'in oyuncu temelli tasarım önerisi de bu bulguyu destekler niteliktedir. Tasarım temasına ilişkin son bulgu oyun içerisinde yer alan tüm butonların ya da tasarım öğelerinin aktif ve çalışıyor olması gerektiği olmuştur. Öğrenciler için, oyun içi reaksiyonlarına hızlı yanıt almaları önemli görülebilir. Nitekim Meşe ve Dursun (2018) oyun içi bildirimlerin hızlı ve sürekli olarak verilmesinin öğrencileri oyunlaştırma sürecinde aktif ve ilgili tutacağını belirtmiştir. González ve Area (2013)'nın eğitsel materyallerde kullanılabilecek oyun bileşenleri içerisinde yer verdiği hızlı ve anlamlı geribildirim de bu bulguyla paralellik göstermektedir. İçerik temasına ilişkin ortaya çıkan ilk bulgu oyun içerisinde kavram karmaşasının önüne geçilmesi gerektiği olmuştur. Oyunlaştırmada kullanılan mobil oyunun anlaşılır olması ve oyun içi bileşenlerin net olması öğrencilerin oyun akışı içinde kalmaları açısından önemli görülebilir. İçeriğe ilişkin diğer bulgular küçük oyunlara daha fazla yer verilmesi ve bu oyunlarda seviyelerin basitten zora doğru sıralanıyor olmasıdır. Bu bulgu gözlem sonucunda ortaya çıkan bulguyla paralellik göstermektedir.

Sınıf öğretmeni ile yapılan yarı yapılandırılmış görüşme sonucunda oyunlaştırma süreci temasında birleşen bulgular ortaya çıkmıştır. İlk bulgu, dijital oyunlaştırma sürecinde sınıf içerisinde oyunların akıllı tahtaya yansıtılarak grupça oynanmasıdır. Oyunlaştırma sürecine tüm öğrencilerin dâhil edilmesi açısından akıllı tahta kullanımı önemli görülebilir. Türkmen ve Soybaş (2019) bu bulguyu destekleyecek şekilde oyun ortamlarının öğrenciler arasında dayanışmayı ve yardımlaşmayı artırdığını ifade etmiştir. Literatürde farklı çalışmalar da oyunlaştırmanın öğrencilerin sınıf içi etkileşimli öğrenme aktivitelerine katılımlarını artırdığını ortaya koymuştur (Hamari ve diğ., 2014; Hanus ve Fox, 2015). Dolayısıyla akı1lı tahta bu etkileşimin, yardımlaşmanın ve takım ruhunun oluşturulabilmesi için destekleyici bir araç olarak kullanılabilir. Oyunlaştırma sürecine ilişkin diğer bulgular öğretmenin oyunlaştırma sürecinde aktif rol alması ve öğrencilerin motivasyonunu üst noktada tutmasıdır. Özellikle mobil oyun üzerinden gerçekleştirilen oyunlaştırma sürecinde tüm öğrencilerin sürece dâhil olması hem oyunlaştırma hem de 
matematik ile ilişkili becerilerin desteklenmesi açısından önemli görülebilir. Oyunlaştırma sürecine ilişkin diğer bir bulgu oyunlaştırma içerisinde öğrencinin oyunda elde ettiği başarı hissini tatmasıdır. $\mathrm{Bu}$ bulgu oyunlaştırma içerisinde öğrencilerin başardığı hissinin verilmesi ve daha çok ödüllendirilmesi gerektiği fikriyle bağdaştırılabilir. Benzer olarak, Çağlar ve Kocadere (2015) oyunlaştırmada öğrencilerin cezalandırılmaması gerektiğini, sadece ödüllendirmenin ön planda olması gerektiğini vurgulamıştır. González ve Area (2013)'a göre de öğrencileri mutlu edecek ve öğrencilere başarma hissini verecek oyun kazanımları eğitsel materyallerde kullanılabilecek oyun bileşeni olarak ön plana çıkmalıdır. Oyunlaştırma sürecine ilişkin son bulgular teknik altyapının hazır olması ve öğretmenin teknolojik okuryazar olmasıdır. Öğrencilerin beklentilerine cevap vermek ve motivasyonlarının kaybolmasını engellemek açısından bu bulgular önemli görülebilir.

Sonuç olarak, mobil oyun kullanılarak gerçekleştirilen sınıf içi oyunlaştırma öğrenciler üzerinde olumlu ve ilgi çekici bir etkiye sahiptir. Oyunlaştırmada kullanılan dijital oyunun tasarım ve içerik bileşenlerinin öğrencilerin beklentilerine uygun bir şekilde yer alması önemli görülmektedir. İlköğretim öğrencilerinin yanı sıra sınıf öğretmeninin de önemli bir rolü bulunmaktadır. Öğretmenin sürece hâkim olması, sınıf yönetimini sağlaması ve aktif hareket etmesi oyunlaştırmayı başarıya ulaştıracak etkenler arasında sayılabilir. Tüm bu bulgular eğitsel mobil matematik oyunu ile ilköğretim öğrencileri için gerçekleştirilecek sınıf içi oyunlaştırmada önemli rol oynayacaktır.

Eğitsel mobil matematik oyunu ile gerçekleştirilen sınıf içi oyunlaştırmaya ilişkin öğretmen ve öğrencilerin deneyimleri ve görüşlerini araştıran bu çalışma sonucunda elde edilen bulgular sadece öğretmenler için değil öğretim tasarımcıları, alan uzmanları, eğitsel oyun geliştiricileri ve daha pek çok kişi için yol gösterici olabilir. Tasarım, içerik ve oyunlaştırma sürecine ilişkin ortaya çıkan bulgular özellikle eğitsel oyun geliştirme ve oyunlaştırmada kılavuz olarak kullanılabilir. Oyunlaştırma sürecinde gözlenen öğrenci duygu ve davranışları müfredat temelli farklı matematik konularının oyunlaştırma ile anlatımında önemli bir destek oluşturabilir. $\mathrm{Bu}$ çalışmadan yola çıkarak ileriki dönemde oyunlaştırmanın sınıf içinde kullanımına ilişkin daha uzun süreli araştırmalar gerçekleştirilebilir ve uzun süreli etkileri değerlendirilebilir. Bununla birlikte okul dışı öğrenme ortamlarında velilerin de dâhil olduğu araştırmalar oyunlaştırmanın farklı öğrenme ortamlarına yaygınlaştırılması açısından önemli görülebilir.

$\mathrm{Bu}$ çalışma, araştırmaya katılan ilköğretim öğrencileri ve sınıf öğretmeninin görüşleri ve deneyimleri ile sınırlıdır. Çalışmanın bir diğer sınırlılığı, nitel araştırma yöntemlerinden durum çalışmasının kullanılmasıdır. İleride gerçekleştirilecek pek çok farklı çalışmada nitel ve nicel yöntemlerin birlikte kullanıldığı araştırmalar daha geniş kapsamlı bulguların ortaya çıkarılmasında etkili olacaktır. Çalışmaya ilişkin son sınırlılık sınıf içi oyunlaştırmada kullanılan Hoverland eğitsel mobil matematik oyunudur. Sınıf içi oyunlaştırmada kullanılabilecek çok farklı tür ve teknolojiyi temel alan oyunların oyunlaştırma süreci içinde araştırılması sonuçların genişletilmesi ve yaygınlaştırılması açısından önemlidir.

\section{Kaynakça}

Abramovich, S., Schunn, C., \& Higashi, R. M. (2013). Are badges useful in education? It depends upon the type of badge and expertise of learner. Educational Technology Research \& Development, 61(2), 217-232. DOI: https://doi.org/10.1007/s11423-013-9289-2

Başkale, H. (2016). Nitel araştırmalarda geçerlik, güvenirlik ve örneklem büyüklüğünün belirlenmesi. Dokuz Eylül Üniversitesi Hemşirelik Fakültesi Elektronik Dergisi, 9(1), 23-28.

Bogdan, R. C., \& Biklen, S. K. (2007). Qualitative research for education: An introduction to theory and methods (5th ed.). Boston: Allyn \& Bacon.

Bozkurt, A., \& Genç-Kumtepe, E. (2014). Oyunlaştırma, oyun felsefesi ve eğitim: Gamification. Akademik Bilişim, 14, 147-156.

Buckley, P., \& Doyle, E. (2014). Gamification and student motivation. Interactive Learning Environments, 24(6), 1162-1175. DOI: 10.1080/10494820.2014.964263

Çengelci, T. (2010). İlköğretim beşinci sınıf sosyal bilgiler dersinde değerler eğitiminin gerçekleştirilmesine ilişkin bir durum çalışması. (Yayımlanmamış doktora tezi). Anadolu Üniversitesi Eğitim Bilimleri Enstitüsü. Eskişehir

Çağlar, Ş., \& Kocadere, S. A. (2015). Çevrimiçi öğrenme ortamlarında oyunlaştırma. Journal of Educational Sciences \& Practices, 14(27), 83-102. 
Deterding, S., Dixon, D., Khaled, R., \& Nacke, L. (2011). From game design elements to gamefulness: defining gamification. 15th international academic MindTrek conference: Envisioning future media environments, ACM.

Dicheva, D., Dichev, C., Agre, G., \& Angelova, G. (2015). Gamification in education: A systematic mapping study. Journal of Educational Technology \& Society, 18(3), 75-88.

Domínguez, A., Saenz-De-Navarrete, J., De-Marcos, L., FernáNdez-Sanz, L., PagéS, C., \& MartíNezHerrálz, J. J. (2013). Gamifying learning experiences: Practical implications and outcomes. Computers \& Education, 63, 380-392. DOI: 10.1016/j.compedu.2012.12.020

Fraenkel, J. R., \& Wallen, N. E. (2006). How to design and evaluate research in education (6th ed.). New York, NY: McGraw-Hill.

Gatti, L., Ulrich, M., \& Seele, P. (2019). Education for sustainable development through business simulation games: An exploratory study of sustainability gamification and its effects on students' learning outcomes. Journal of Cleaner Production, 207, 667-678. DOI: 10.1016/j.jclepro.2018.09.130

González, C., \& Area, M. (2013). Breaking the rules: Gamification of learning and educational materials. In 2nd international workshop on interaction design in educational environments, 7-53.

Hamari, J., Koivisto, J., \& Sarsa, H. (2014). Does gamification work? --a literature review of empirical studies on gamification. In 47th Hawaii international conference on system sciences (HICSS), IEEE (pp. 3025-3034).

Hanus, M. D., \& Fox, J. (2015). Assessing the effects of gamification in the classroom: A longitudinal study on intrinsic motivation, social comparison, satisfaction, effort, and academic performance. Computers \& Education, 80, 152-161. DOI: 10.1016/j.compedu.2014.08.019

Jagušt, T., Botički, I., \& So, H. J. (2018). Examining competitive, collaborative and adaptive gamification in young learners' math learning. Computers \& Education, 125, 444-457. DOI: 10.1016/j.compedu.2018.06.022

Karaşahinoğlu, Ş. (2018). Çocuklara yönelik tablet uygulamalarında tasarım yaklaşımları ve bir mobil uygulama denemesi. (Yayımlanmamış sanatta yeterlik tezi). Hacettepe Üniversitesi Güzel Sanatlar Enstitüsü. Ankara

Karayılan, M., Çakmak, G., \& Güzel, R. (2018). Bitki ve hayvanlarda üreme, büyüme ve gelişme ünitesinin değerlendirme sürecinde kullanılan oyunlaştırma etkinliğinin öğrencilerin fen bilimleri dersindeki başarılarına etkisi. Dicle Üniversitesi Ziya Gökalp Eğitim Fakültesi Dergisi, 34, 60-69. DOI: http://dx.doi.org/10.14582/DUZGEF.1910

Marshall, C., \& Rossman, G. B. (2011). Designing qualitative research (5th ed.). Thousand Oaks, CA: Sage Publications.

Meşe, C., \& Dursun, Ö. Ö. (2018). Oyunlaştırma bileşenlerinin duygu, ilgi ve çevrimiçi katılıma etkisi. Eğitim ve Bilim, 43(196), 67-95. DOI: 10.15390/EB.2018.7726

Miles, M. B., \& Huberman, A. M. (1994). An expanded sourcebook: Qualitative data analysis (2nd ed). Thousand Oaks, CA: Sage Publications.

Ozan Leymun, Ş., Odabaşı, H. F., \& Kabakçı Yurdakul, I. (2017). Eğitim ortamlarında durum çalışmasının önemi. Eğitimde Nitel Araştırmalar Dergisi- Journal of Qualitative Research in Education, 5(3), 369-385. DOI: 10.14689/issn.2148- 2624.1.5c3s16m

Özen, F., \& Hendekçi, E. A. (2016). Türkiye'de eğitim denetimi alanında 2005-2015 yılları arasında yayımlanan makale ve tezlerin betimsel analizi. OPUS Uluslararası Toplum Araştırmaları Dergisi, 6(11), 619-650.

Sarı, A., \& Altun, T. (2016). Oyunlaştırma yöntemi ile işlenen bilgisayar derslerinin etkililiğine yönelik öğrenci görüşlerinin incelenmesi. Turkish Journal of Computer and Mathematics Education, 7(3), 553-577.

Türkmen, G. P., \& Soybaş, D. (2019). The effect of gamification method on students' achievements and attitudes towards mathematics. Bartın Üniversitesi Eğitim Fakültesi Dergisi, 8(1), 258-298. DOI: $10.14686 /$ buefad.424575

Türnüklü, A. (2000). Eğitimbilim araştırmalarında etkin olarak kullanılabilecek nitel bir araştırma tekniği: Görüşme. Kuram ve Uygulamada Egitim Yönetimi Dergisi, 6(4), 543-559. 
Van Roy, R., \& Zaman, B. (2018). Need-supporting gamification in education: An assessment of motivational effects over time. Computers \& Education, 127, 283-297. DOI: 10.1016/j.compedu.2018.08.018

Villagrasa, S., Fonseca, D., Redondo, E., \& Duran, J. (2014). Teaching case of gamification and visual technologies for education. Journal of Cases on Information Technology, 16(4), 38-57. DOI: $10.4018 /$ jcit.2014100104

Yıldırım, A., \& Şimşek, H. (2011). Sosyal bilimlerde nitel araştırma yöntemleri (8. Baskı). Ankara: Seçkin Yayıncılık

\section{Extended Abstract}

\section{Introduction}

Gamification is defined as using game elements in non-gaming contexts (Deterding, Dixon, Khaled \& Nacke, 2011). All game elements need to be organized in accordance with the dynamics of the related subject area. González and Area (2013) found in their study that students could improve their cognitive skills through gameplay practices. They also stated that gamification in education creates an informal learning experience for learners. There have been several gamification related studies especially in the field of education. According to Domínguez et al. (2013), students included in gamification activities got higher scores in practical homework assignments. Jagušt, Botički and So (2018) found that simple game mechanics, such as badges, rewards, and points can be used for gamification practices to be held in classrooms. Hamari et al. (2014) revealed that gamification in education not only attracts the attention of students but also motivates them to attend learning activities. Although gamification is a hot and trending topic, there is still a need for more studies considering different research methodologies (Hamari, Koivisto \& Sarsa, 2014; Hanus \& Fox, 2015). Therefore, the main aim of this study is to conduct a case study for deeply investigating the digital game-based gamification process in the teaching and learning context. The research questions of the study are as follows:

- What are the experiences of a primary school teacher and students regarding in-class gamification with the educational mobile mathematics game?

- What are the views of a primary school teacher and students regarding in-class gamification with the educational mobile mathematics game?

\section{Method}

The main research method of the study was a qualitative case study. One teacher and twenty students from a 3rd -grade class in a state primary school participated in the study. The data collection period started in February of 2020. The teacher gamified the classroom by presenting "Hoverland" mobile game via projector. The teacher noted all badges students achieved during the gamification process. Gamification activities lasted 80 minutes in total in two different classes. Hoverland is a digital mobile game targeting primary school students. The game can be played on both mobile and tablet platforms. "Hoverboy" or "hovergirl" character tries to accomplish the mathematics related tasks presented in an open world game environment. Observation and interview forms were used to collect data. Descriptive and content analysis were applied for analyzing data. For the trustworthiness of the study, triangulation of the data collection tools, expert review and inter-coder reliability strategies were implemented.

\section{Findings}

According to the game play findings of observations, digital gamification attracted the attention and interests of students. In addition, students preferred animated visuals in games rather than static visuals. Moreover, students need guidance in playing digital games. Furthermore, structured and meaningful feedbacks should be given to each move of the students in gameplay. Lastly, there should be levels in presenting the games especially for creating mini-games for students. Based on the gamification findings of observations, students tended to save badges they gained during the gamification. This motivated students to attend gamification activities in class. Additionally, attending the gamification activities as a group led students to take responsibilities and interact with their peers. According to the observation findings related with the role of teacher, class management was the hardest situation for the teacher to handle during the gamification process.

Based on the content analysis of semi-structured interviews with students, two main themes emerged. These themes were "design" and "content". According to the findings regarding with the theme of 
design, in-game characters or visuals should be dynamic. Additionally, both girl and boy characters should be used in the design of mobile game. Lastly, all design elements or buttons presented in the educational mobile game should be functional and working properly. According to the findings regarding with the theme of content, there should be no confusion of concepts presented in the mobile game. In addition, there should be more small games aiming to support the mathematical skills of students. Lastly, there should be levels in games and these levels should be presented from easy to hard. According to the content analysis of the semi-structured interview with the teacher, only one theme, namely gamification appeared. Based on the findings, digital games should be played in groups during the gamification process. In addition, teacher should be active during gamification. Moreover, teacher should keep motivation of students at highest level. Furthermore, there should be no technical error for proper gamification. Lastly, teacher should be technology literate for implementing gamification successfully.

\section{Conclusion}

The gamification guidelines proposed in this study can be helpful for teachers, instructional technologists, subject matter experts and several people working in this field. The experiences and views of teacher and students can play a supportive role in presenting different mathematical concepts via gamification. As a future study, long-term research can be conducted to evaluate the effectiveness of digital gamification in classroom contexts. On the other hand, research studies including the parents can extend the scope of the gamification studies.

\footnotetext{
* Bu çalışma İstanbul Bilgi Üniversitesi AK 85039 nolu "ilköğretim öğrencilerine yönelik dijital oyunlaştırma ile müfredat temelli matematik konularının öğretimi ve etkililiğinin araştırılması” BAP projesi ile desteklenmiştir. Yazar destek için İstanbul Bilgi Üniversitesine teşekkür eder.

* Bu çalışmanın gerçekleştirilebilmesi için İstanbul Bilgi Üniversitesi İnsan Araştırmaları Etik Kurulundan 12 Şubat 2019 tarihinde 2019-40660-15 sayılı etik kurul izin belgesi alınmıştır.
} 